Article

\title{
Has China's Oil Investment in Belt and Road Initiative Countries Helped Its Oil Import?
}

\author{
Benye Shi and Tian Cai * \\ School of Economics, Jilin University of China, Changchun 130012, China; shibenye@mails.jlu.edu.cn \\ * Correspondence: caitian0607@mails.jlu.edu.cn
}

Received: 16 March 2020; Accepted: 12 June 2020; Published: 19 June 2020

check for updates

\begin{abstract}
Energy cooperation is an important part of the Belt and Road Initiative (BRI). As China's investment in One Belt One Road countries has increased substantially, a natural question is whether the investment in the BRI countries can contribute to its oil import since it is the most critical part of the national energy security strategy. By employing a dataset that includes the oil import from BRI countries and the oil-related investment in these countries, along with other control variables, an econometric analysis is conducted to investigate the relationship between these two variables. The estimation results provide supporting evidence for the hypothesis that China's oil investment in BRI countries has helped enhance its oil security. Specifically, investment in BRI countries increases the oil import volume from the host country and diversifies China's sources of imports. Further analysis also reveals that the effects do not differ by investment mode, e.g., greenfield or mergers and acquisitions (M\&A).
\end{abstract}

Keywords: overseas investment; Belt and Road initiative; oil security; oil import

JEL Classification: F21; Q48

\section{Introduction}

During his visits to Central and Southeast Asian countries in 2013, President Xi Jinping proposed to jointly build the "Silk Road Economic Belt" and "21st-Century Maritime Silk Road", which later became known as the Belt and Road Initiative (hereinafter referred to as "BRI"). The BRI strategy is widely regarded as a means of enhancing the openness of China and a wider and deeper cooperation with the world, especially in the countries covered by the BRI strategy.

Energy cooperation is an important part of the BRI. Energy resources are very abundant in the countries along the Belt and Road. By the end of 2015, the total proven reserves of energy resources reached 758.73 billion tons of standard coal in the countries along the Belt and Road, which accounts for $52.27 \%$ of the world's reserves [1]. Among the countries along the Belt and Road, Russia, Central Asian and the Middle East have always been China's important sources of energy imports, and also important destinations for Chinese enterprises' overseas investment in recent years. The Chinese overseas direct investment has expanded at a rapid pace, increasing from 28.6 billion USD in 2003 to 183 billion USD in 2017. The flow experienced a significant jump in the year 2014 in response to the BRI strategy. In 2017, the investment in BRI countries accounted for almost half of China's total overseas investment.

China's government and many scholars consider overseas investment in the energy sector an instrument for enhancing China's energy security [2,3]. As the investment in BRI countries becomes more and more important, a natural question is whether the energy investment in BRI countries can contribute to China's energy security, especially by increasing its oil import since oil security is the most critical part of the national energy security strategy. There has been a debate on whether China's overseas investment can help enhance its energy security [4-7]. Policy makers, the business community, 
think tanks and scholars involved in this topic tend to embrace the idea, explicitly or implicitly, that Chinese outbound investment could enhance China's energy security. This is, however, a rarely tested hypothesis, and quantitative studies of the issue are limited. Further clarifying this debate is important not only for academics but also for Chinese policymakers and international stakeholders.

This study attempts to fill in the void by investigating whether Chinese investment in the BRI countries help improve its energy security using a dataset created by merging the China Global Investment Tracker data and the Chinese Customs oil import data. Three specific hypotheses are tested. Has China's energy investment in BRI countries diversified its import sources? Can it increase the volume of oil imported from that country? Are these impacts differentiated for greenfield investment and mergers and acquisitions (M\&A)?

We start with an overview of the status of China's oil import and the energy investment in the BRI countries. Then the oil imports from the BRI countries are regressed on the energy investment in these countries along with other control variables to investigate the relationship between these two variables. The estimation results provide supporting evidence for the hypothesis that China's investment in BRI countries help enhance its energy security. Specifically, investment in BRI countries increases the oil import volume from the host country and diversifies China's sources of imports. Further analysis also reveals that the effects do not differ by investment mode.

Our study contributes to the literature in two aspects. First, as far as we know this is the first quantitative study to explore whether China's BRI strategy can help improve its energy security. Energy cooperation is arguably an important part of the BRI, but little has been done to empirically test this hypothesis. Secondly, it also enriches the literature by studying the behavior of China's overseas investment, which has increased substantially over the past decade and played a larger role in shaping the global economy. Our finding supports the argument that this national strategy is also a motivation for Chinese overseas investment, and it has been implemented successfully.

The remainder of the paper proceeds as follows. The next section briefly presents the background on the energy cooperation of China and the BRI countries, as well as the literature review. Section 3 presents the empirical model. Results on the relation between overseas investment and China's energy imports are presented in Section 4. The last section concludes and provides policy implications.

\section{Background and Literature Review}

\subsection{China's Oil Import and Energy Investment in BRI Countries}

Alongside its dramatic economic growth over the past four decades, China has become the world's largest energy consumer, accounting for $21 \%$ of the world's energy consumption, and was a net importer of coal, oil, and natural gas in 2018 [8]. In the same year, China imported 460 million tons of crude oil and surpassed the US as the world's largest oil importer. Its oil import dependence rate also reached a record high of nearly 70\% [9]. Even with slower economic growth within the "New Normal" economic environment, China's oil consumption and its important dependencies are expected to continue to grow over the next two decades [10]. In this context, energy security, especially oil security, is considered as the top concern of China's policymakers.

On the whole, the proven reserves of energy resources in the countries along the Belt and Road have played an important role internationally, especially their gas and oil reserves. In terms of the total amount of energy, these countries accounted for 401.45 billion tons of coal, 133.15 billion tons of oil and 143.3 trillion cubic meters of gas, which account for $45.03 \%, 55.62 \%$ and $76.68 \%$ of the world's reserves, respectively. At the national scale, China has imported oil from Russia, Saudi Arabia and 23 other countries along the Belt and Road.

The Chinese government has long promoted overseas investment in the energy sector. In the 10th Five-Year Plan (2001-2005), the Chinese government first proposed to "make full use of both domestic and foreign resources and launch the 'going out' strategy of Chinese enterprises". The following Five-Year Plans state that China will accelerate mutually beneficial cooperation in exploring, developing 
and processing energy resources worldwide. In China's 12th Five-Year Plan period, overseas oil investment, strategic petroleum reserves and unconventional gas development were considered the key elements of China's energy security strategies. The "going out" strategy was further strengthened in the 13th Five-Year Plan with "openness" and capacity cooperation with the "Belt and Road" countries [11]. These policies encouraging China's overseas investment have stimulated a substantial increase in its total scale, from 6.6 billion USD to 55.2 billion USD between 2005 and 2017.

The countries along the "Belt and Road" have good resource conditions and have been a key area for China's energy outbound investment cooperation in the past ten years. From 2005 to 2008, China's total energy direct investment in countries along the Belt and Road accounted for more than half of the total (Figure 1). There has been a decline between 2010 and 2012. In recent years, with the introduction of the BRI strategy, China's economic cooperation with the countries along the route has further strengthened, and energy investment in the BRI countries has also picked up significantly. The BRI countries account for $51.5 \%$ of the total foreign energy investment.

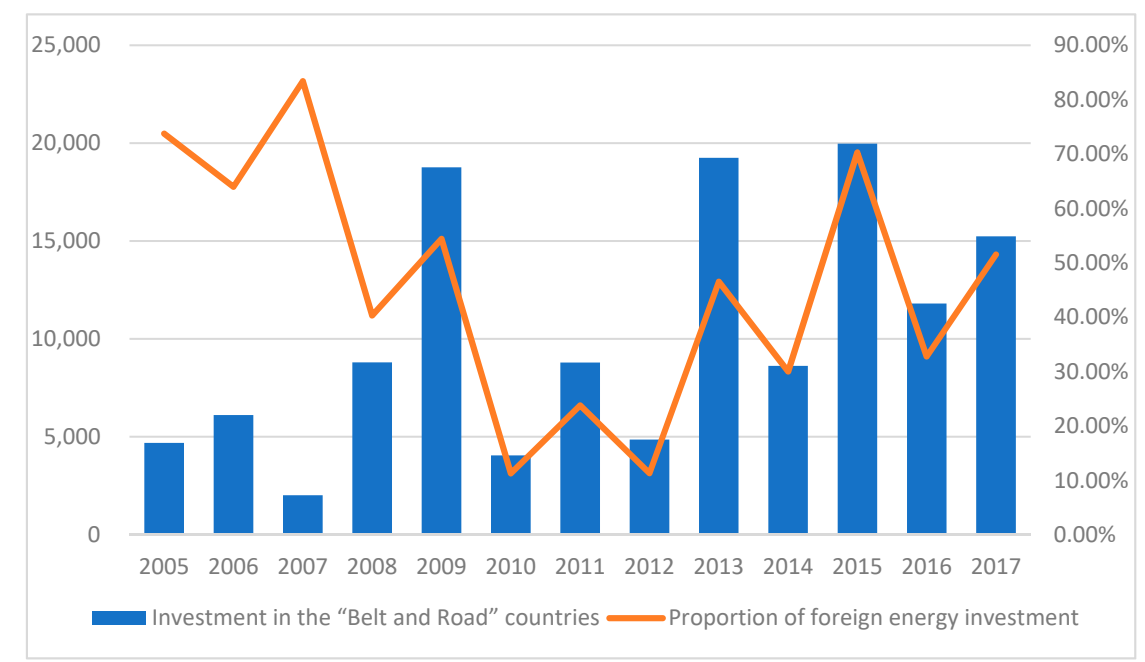

Figure 1. Energy investment in the Belt and Road Initiative (BRI) countries (Unit: USD million). Data source: China Global Investment Tracker.

From the perspective of investment structure, although traditional fossil energy, especially oil and gas projects, is the main area of China's Belt and Road region, new energy has been developing rapidly in recent years. The investment volume of new energy, such as solar energy and wind energy, has increased significantly (Figure 2).

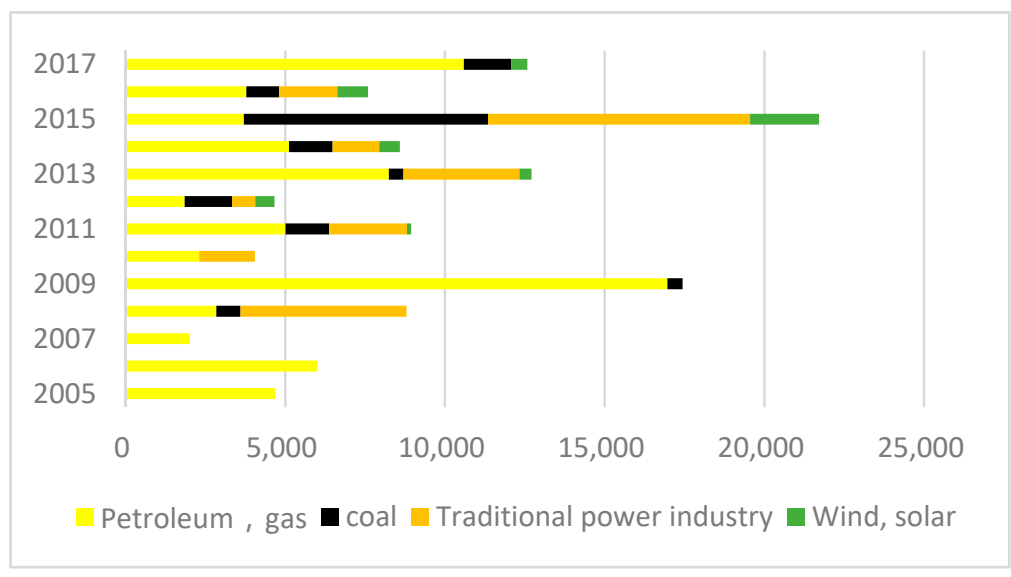

Figure 2. Investment structure in the BRI countries. Data source: China Global Investment Tracker. 


\subsection{Literature Review}

\subsubsection{Energy Security}

The concept of energy security has been widely used in academic and policy debates, but there has been no consensus on its precise definition. There are different concepts of energy security in the literature [12-14]. A narrow definition focuses on the most important aspect: the availability the energy supply, which is maintained at a stable level that can satisfy the demand of national development [15-17]. A comprehensive definition would include many dimensions, such as physical availability, price affordability and environmental sustainability $[18,19]$.

For oil importing countries, oil is the key to energy security [20-22]. Alhajji [23] points out that policymakers often limit the concept of energy security to oil and concerns about the security of oil imports dominate policy thinking and making. Moreover, the vast majority of the literature on energy security focuses on oil [6,24].

In addition to securing the quantity of oil to meet the domestic demand, the diversification of oil import sources is used as one of the strategies to enhance the energy security in oil-importing countries [25-27]. Relying on a single source for oil imports, in general, is far riskier than importing oil from multiple sources [28]. Having multiple suppliers provide security and reduce vulnerability in cases of temporary or permanent disruption of supply.

\subsubsection{Energy Trade and Investment in the Belt and Road Countries}

The Belt and Road Initiative provides new historical opportunities and new challenges for international cooperation in the energy field, which attracted researcher to examine a range of related topics in this field. Du and Zhang [29] analyzed China's overseas direct investment against the background of BRI, finding that it rose significantly in the BRI countries, and Central Asia, West Asia, Western Europe and Russia were all highlighted as favorable destinations for Chinese overseas direct investment. By using the fuzzy integrated evaluation model, Duan et al. [2] evaluated China's energy investment risk for nations along the Belt and Road. Han et al. [30] examined the effects of trade integration and regional cooperation on energy efficiency convergence.

On the basis of existing cooperation, how to further promote cooperation in the energy field, tap potentials and avoid risks are important topics that need to be studied. Many scholars have made beneficial explorations. Zha [31] proposed that the logical basis of energy cooperation between China and the countries along the route cannot be narrowly regarded as improving energy security and transferring excess capacity. Gao and Yang [32] proposed that the key cooperation directions of the BRI energy cooperation include building an international energy governance platform; an infrastructure interconnection network; creating an upgraded version of international oil and gas cooperation; strengthening efficient and clean energy technology cooperation; and promoting the services and equipment to go out. Wang [33] believes that China and the Belt and Road countries have great potential for energy cooperation, but also face risks such as geopolitics, policy changes, price yfluctuations and legal compliance. Xu et al. [34] used 37 sub-indicators to conduct risk assessments of the countries along the "Belt and Road" from six dimensions: an economic foundation, social risk, political risk, a Chinese factor, an energy factor, and environmental risk.

In some BRI countries, there is a relatively fragile ecological environment and serious environmental pollution. Several studies point out that the BRI should be steered towards green and low-carbon development, as well as how to address the challenges of the Green Belt and Road Initiatives. Taghizadeh-Hesary and Yoshino $[35,36]$ highlight the challenges of green financing and investment in the energy sectors in BRI countries. Sun et al. [37] identified 10 core low-carbon financial risk factors that could potentially derail the project. Yoshino et al. [38] proposed how to utilize social funding to address the gap in green energy financing. 


\subsubsection{China's Overseas Investment and Energy Security}

The third line of literature focuses on the role of China's overseas investment in enhancing its energy security. Various arguments that China's overseas investment aims to enhance China's energy security have been proposed. The most straightforward argument is that China's overseas investment has been identified as an important strategy by the Chinese government to promote energy security in its five-year plans and long-term energy planning. Tan [3] provides a comprehensive review of China's overseas investment in energy, including its development stages, the supporting policies, the decision-making process, the investment models and the challenges. Many studies accept the premise that Chinese energy investment can help promote energy security by increasing oil and gas reserves, expanding production and diversifying the sources of supply [39,40].

This energy security motivation is also indirectly supported by the observation that the investment decisions of China's National Oil Companies (NOCs), who are major players in China's overseas investment, are not often purely based on business considerations. For example, they often pay a higher price to acquire energy resources than competitors do, choose locations with poor institutional quality or even suffer great losses at face value to acquire foreign assets. These behaviors show that overseas energy investment by the NOCs is more likely driven by national security concerns rather than pure business motives [41,42].

Some researchers argue that China's overseas energy investment can indirectly help to enhance oil security through several channels in addition to securing equity oil, including promoting long-term relationships with oil-producing countries, investing and lobbying for the construction of transportation routes that favor China and enhancing international oil supply. Thus, overseas investment may indirectly contribute to China's energy security as well [43,44].

Opposing arguments have also been raised. Chinese NOCs, the major players in overseas investment, are profit-seeking investors and, thus, do not prioritize energy security above their business operations. They are considered to be independent market actors and do not necessarily act as an extended arm of the Chinese government [45]. They have the capacity to formulate and implement their own investment strategies for their own interests. Protecting Chinese energy security could be a nominal argument that they use to persuade Beijing to actively support their global investments through energy diplomacy [44]. Gholz et al. [46] consider that the real reason for the expansion of China's loan-for-oil deals is not energy security but as a kind of subsidy to the NOCs, which have the political power to obtain such a subsidy.

Jiang and Ding [40] claims that partnering with international oil companies can help Chinese NOCs acquire management experience and technology in areas such as unconventional oil and gas, deep water and liquefied natural gas. Zhang [6] argues that energy investment can help the Chinese government diversify its foreign exchange reserves away from low-yielding financial instruments, such as US Treasury Bonds.

This study brings these three lines of literature together. There have been limited quantitative studies investigating the role of overseas investment in the energy sector in enhancing the oil security of China, especially in the BRI countries. Given the above discussion, the main hypothesis is that China's overseas investment in the energy sector can help to increase the volume of imports.

\section{Method and Materials}

\subsection{Theoretical Background and Estimation Model}

It is hypothesized in the literature that Chinese energy investment can help promote energy security by increasing oil and gas reserves, expanding production and diversifying the sources of supply. In our study, the hypothesis that China's overseas energy investment in BRI countries enhances its energy security is tested from two angles: whether it helps diversify China's import sources by increasing the probability of importing from a host country (extensive margin), and whether it increases the imported volume from a destination country (intensive margin). In international trade theory, 
an intensive margin refers to the trade volume increasing through time while the extensive margin refers to the new establishment of a trade relationship [47,48]. The commonly used vehicle in the empirical literature to test such theories is the gravity-type equation.

Overseas investment in a host country can bring new oil suppliers through two channels. First, China may acquire oil assets in the country and, thus, gain more control over oil resources. Secondly, the learning and information effects of the investment can reduce uncertainty around oil imports for Chinese oil importers. The diversification means that there are more oil import sources available. We measure the diversification by the probability of establishing an oil trade relationship. The increase in the probability of oil import from a country implies more chances of establishing a new oil trade relationship, and thus more import sources. It is a commonly adopted indicator in the international trade literature.

To evaluate the impact of energy investment on the diversification of oil imports, we specify a logit model to estimate the likelihood of importing from a given country, as follows:

$$
\begin{gathered}
Y^{*}{ }_{i j t}>0=a+\lambda^{*} \log \left(E I_{i t}\right)+X \beta+u_{i}+e_{j}+v_{t}+\varepsilon_{i j t} . \\
Y_{i j t}^{*}=\left\{\begin{array}{l}
1 \text { if } Y_{i j t}>0 \\
0 \text { if } Y_{i j t}=0
\end{array}\right\}
\end{gathered}
$$

where $Y^{*} i j t$ is a binary variable taking the values 1 or 0 . It takes 1 if $Y_{i j t}$, which is firm $j^{\prime}$ s imported oil from country $i$ in year $t$ being greater than 0 ; otherwise it is denoted by $0 . E I_{i t}$ is China's cumulative oil (energy) investments in country $i$ as of year $t$ and the variable of interest. The coefficient $\lambda$ measures the probability of an increase in oil imports if the investment increases by one percent. $X$ is a vector of control variables that may affect oil imports from country $i$ in year $t . v_{t}$ is a vector of year dummies to capture time-variant unobserved heterogeneity. $u_{i}$ denotes country fixed effects and captures many of the time-invariant, unobserved country-specific characteristics included in the gravity model, such as geographic distance, among others. $e_{j}$ represents a firm's fixed effects and allows us to take into account unobserved heterogeneity across firms that is potentially correlated with their import decisions. Finally, $\varepsilon_{i j t}$ is the error term, which may be correlated within a country.

To evaluate whether the overseas investment can help increase the imported volume from a destination country, an estimation equation relating China's energy investment and its volume of oil imports as well as other control variables is specified as follows:

$$
y_{i j t}=\beta+\gamma^{*} \log \left(E I_{i t}\right)+X \beta+u_{i}+e_{j}+v_{t}+\varepsilon_{i j t}
$$

where $y_{i j t}$ is the logarithm of firm $j$ 's imported oil from country $i$ in year $t . E I_{i t}$ is China's cumulative oil (energy) investments in country $i$ as of year $t$ and the variable of interest. The coefficient $\gamma$ measures the impact of increasing investment on import volumes. $X$ is the same vector of the control variables as in Equation (1). $v_{t}, e_{j}, u_{i}$ and $\varepsilon_{i j t}$ are defined the same as in Equation (1).

The variables that can affect oil imports from different countries should also be included as control variables. Following previous studies of oil trade [49,50], four types of variables are specified. First, GDP measures the market sizes of the source countries and is expected to positively impact the oil trade flow as a major driver of trade volume. Secondly, GDP per capita measures the incomes of the source countries. A high income implies that the source country has a higher energy demand and therefore negatively affects China's imports from a country. Thirdly, a country's risk may negatively affect imports from a country, as importers may rationally reduce their imports from high-risk countries. Finally, oil production and consumption in the import source country are measured in terms of annual oil production or consumption in barrels. Oil production should positively affect China's imports, whereas oil consumption should have a negative impact.

In addition, we explored whether the investment type matters when estimating the effect of oversea investment on oil imports. We also ran separate estimations for greenfield investment and 
M\&A. Greenfield investment can help to expand local production capacity more than M\&A does, leading to more oil supply as a result. In this sense, greenfield investment can provide Chinese investors with more control.

\subsection{Data}

Our final dataset had 64,512 observations for 123 importing firms and 65 BRI countries, covering the period 2005-2013.Th e data were compiled from several sources. The list of the belt-road countries is from the "One Belt One Road" database hosted by the Social Sciences Academic Press (China). Data on oil imports were obtained from the Chinese Customs Database. The database contains transaction-level information, including the time, importer, transaction value, quantity and importing source country. These data can therefore be aggregated according to the import source country and year.

The overseas energy investment data came from the China Global Investment Tracker [51], which covers Chinese investments announced in the open-source media with a value over $\$ 100$ million. These data can serve as a reasonable proxy for China's large-scale investments [52]. Several sources provide data on China's overseas investment, including official data sources, such as China's Ministry of Commerce, the National Bureau of Statistics and the State Administration of Foreign Exchange. On an aggregate level, the tracker data and official data reported by the Ministry of Commerce have small discrepancies. However, the tracker dataset records the final destination of the investment, as opposed to the official data from the Ministry of Commerce only recording the first destination and leading to large bias. The disadvantage is that it may under-represent smaller scale investments (smaller than $100 \$$ million). Since energy-related investment often involves large amounts of money, the tracker data can be considered as having good representativeness.

GDP and GDP per capita were taken from the World Bank Development Indicator Database, and the indicator of country risk was taken from the Economist Intelligence Unit Country Risk Model Database. The Country Risk Model is developed by the Economist Intelligence Unit; it provides risk scores that can be compared across countries and over time for six risk categories (sovereign debt, currency, banking sector, political, economic structure and overall countries risk). We used the overall country risk index to measure the market risk conditions of the host countries. More details on the database can be found on the following website: https://www.eiu.com/handlers/publicDownload. ash $\mathrm{x}$ ?mode $=\mathrm{m} \& \mathrm{fi}=$ risk-section/country-risk-model.pdf), and the oil production and consumption data came from the BP Statistical Review of World Energy [8]. Table 1 presents the summary statistics of the variables.

Table 1. Summary statistics.

\begin{tabular}{ccccc}
\hline Variable Name & Max & Min & Mean & S.D. \\
\hline Market size (billion US dollar) & 2390 & 423 & 263 & 423 \\
Income (1000 US dollar) & 96 & 0.5 & 12.3 & 15.7 \\
Economic risk & 89.6 & 15.5 & 47.3 & 12.9 \\
Oil production (billion barrels) & 4.25 & 0 & 0.44 & 0.79 \\
Oil consumption (billion barrels) & 7.59 & 0 & 039 & 0.93 \\
Cumulative investment in oil sector (billion US dollars) & 9.87 & 0 & 0.42 & 1.4 \\
Cumulative greenfield investment (billion US dollars) & 5.66 & 0 & 0.2 & 0.84 \\
Cumulative M\&A (billion US dollars) & 9.64 & 0 & 0.22 & 0.92 \\
\hline
\end{tabular}

We explored whether the investment type matters when estimating the effect of OFDI on oil imports, and ran separate estimations for greenfield investment and M\&A. Greenfield investment can help to expand local production capacity more than M\&A does, leading to more oil supply as a result. Harms and Méon (2018) argue that greenfield investment can contribute more to expand a host country's capital stock than M\&A does because the latter is more like a rent that accrues to the previous owners. A similar logic applies in this context. Greenfield investment can help China gain more control of the reserve and production capacity, more so than M\&A does, leading to more oil 
supply as a result. In this sense, we expect that greenfield investment can lead to a more significant effect on oil import than M\&A.

\subsection{Identification Strategy}

The first issue in estimation is the potential endogeneity caused by reverse causality. Since the dependent variable is annual oil imports at the firm-destination level, and the key explanatory variable, overseas investment, is aggregated at the destination-country level, the aggregate-level variables should affect the individual variables, but the reverse does not hold. Thus, the potential endogeneity problem caused by reverse causality should be mitigated.

The second issue is that a large number of zero-value in import trade poses a significant challenge in the estimation and using Ordinary Least Square (OLS) would bias the estimation. In Equation (1), the dependent variable is a binary outcome variable, representing the probability of a positive oil import. We adopted a logistic regression analysis, which has also been extensively used to investigate the relationship between binary or ordinal response probability and explanatory variables. In Equation (2), we chose EK-Tobit models because the oil import censors around zero. The dependent variable is the logarithm of the volume of imports and excludes observations with zero-value imports. If the process for eliminating this zero value is non-random, sample selection bias is inevitable. The EK-Tobit model proposed by Eaton and Kortum [53] is employed to solve the zero-value problem in trade. It is suitable to handle the censoring problem and avoid selection bias. Zero trade may arise for several reasons; it may reflect actual trade transactions, or the exporter/importer may have chosen to report only data above a certain threshold. Thus, Eaton and Kortum suggest that the threshold value could be a maximum likelihood estimation of the censoring point as implied by trade models with fixed trade costs. They therefore replace the zero values with the minimum trade value exported by a certain company to a certain country and use an interval regression for estimation. Compared with the traditional Tobit model, the EK-Tobit model not only has no exclusion restrictions but also better controls for country or country pair effects. Head and Mayer [54] compared a variety of different zero-value trade processing methods, affirming the validity of the EK-Tobit model estimation, and consider that method to be one of the most effective methods in this setting. Furthermore, this method is currently widely used in the estimation and identification of trade models $[55,56]$.

Since the explanatory variable of interest is China's energy investment in a host country. In theory, the host country's characteristics are correlated with the investment and should be controlled to obtain a consistent estimation. The fixed-effect model is suitable in this case because it controls for the unobserved country's characteristics.

There could be an issue of multicollinearity as some of the explanatory variables could be highly correlated. This multicollinearity might cause unstable and unreliable estimates. We ran the variance inflation factor (VIF) test for all the variables. All the VIF values were smaller than 5 and the VIF of the investment variable was only 1.2 , which indicate that the multicollinearity issue is not serious.

\section{Results and Discussion}

Table 2 reports the estimation results for Equation (1). Year, country and firm fixed effects are included in all models, but the results are not reported owing to limited space. Columns (1) and (2) report the results of estimating Equation (1) using OLS and logit models, respectively. This regression examines whether overseas oil investment in a country increases the probability of importing oil from that country. Since the logit model results have more explicit economic meanings than the OLS results have, we discuss the results of the logit model. The estimation shows that China's energy investment in a BRI country is positively associated with the probability of importing oil from that country. The point estimate of the investment coefficient is 0.007 , which corresponds to a marginal effect of 0.013 , implying that a $1 \%$ increase in China's investment in a host country's oil sector leads to a $1.3 \%$ increase in the probability of importing from that country on average—at the firm level. 
Table 2. Estimation results for the probability of oil import (Equation (1)).

\begin{tabular}{|c|c|c|c|}
\hline Variables & OLS & LOGIT & LOGIT \\
\hline & (1) & (2) & (3) \\
\hline Overseas investment & $\begin{array}{c}0.0003^{* * * *} \\
(0.016)\end{array}$ & $\begin{array}{l}0.007^{* * * *} \\
(0.0012)\end{array}$ & \\
\hline Greenfield & & & $\begin{array}{c}0.0084 * \\
(-0.0040)\end{array}$ \\
\hline M\&A & & & $\begin{array}{c}0.0091^{* *} \\
-0.0035\end{array}$ \\
\hline Market size & $\begin{array}{c}0.0390^{* * *} \\
(0.0128)\end{array}$ & $\begin{array}{l}2.081 * * \\
(0.9981)\end{array}$ & $\begin{array}{l}8.071 * \\
(4.509)\end{array}$ \\
\hline Income & $\begin{array}{c}-0.041 \\
(0.0133)\end{array}$ & $\begin{array}{l}-0.291 \\
(0.926)\end{array}$ & $\begin{array}{c}10.25^{* *} \\
(4.17)\end{array}$ \\
\hline Economic risk & $\begin{array}{c}-0.0001 \\
(-0.0001)\end{array}$ & $\begin{array}{l}-0.0089 \\
(0.0094)\end{array}$ & $\begin{array}{l}-0.0347 \\
(0.0444)\end{array}$ \\
\hline Oil production & $\begin{array}{c}0.011 * \\
(0.0037)\end{array}$ & $\begin{array}{c}0.4757^{*} \\
(0.259)\end{array}$ & $\begin{array}{c}3.469 * \\
(-1.251)\end{array}$ \\
\hline Oil consumption & $\begin{array}{l}-0.0096 \\
(-0.007)\end{array}$ & $\begin{array}{c}-0.823 \\
(0.6432)\end{array}$ & -3.152 \\
\hline Constant & $\begin{array}{c}-0.771^{* * *} \\
(-0.24)\end{array}$ & $\begin{array}{l}-34.84 \\
(-20.14)\end{array}$ & $\begin{array}{c}-2.454^{* * *} \\
(0.115)\end{array}$ \\
\hline Year FE & Yes & Yes & Yes \\
\hline Country FE & Yes & Yes & Yes \\
\hline Firm FE & Yes & Yes & Yes \\
\hline $\mathrm{R}^{2}$ & 0.186 & 0.232 & 0.243 \\
\hline Observations & 64,512 & 64,512 & 64,512 \\
\hline
\end{tabular}

Notes: Robust standard errors clustered at the firm level are reported in parentheses. ${ }^{* * *} p<0.01,{ }^{* *} p<0.05,{ }^{*} p<0.1$.

Two types of investment forms were also regressed to detect whether they show different pattern, the result of which are shown in Column (3). It is speculated that greenfield investment can give more control to investors. Greenfield investment can contribute more to expand the host country's capital stock than M\&A since the latter is more representative of a rent accruing to previous owners [57]. Thus, greenfield investment can help expand local production capacity more than M\&A, leading to more oil supply. The results are reported in Column (3) and show that greenfield investments and M\&A both positively affect the diversification of the sourcing countries. A t-test shows that the coefficients of these two variables are not statistically different, and, thus, we find no evidence for heterogeneous effects by investment mode.

Table 3 report the results for Equation (2) using the OLS and EK-Tobit estimators, respectively. This model aims to determine whether investment in a country increases the volume of imports from that country. The coefficients of energy investment are statistically significant and positive in all regressions, implying that investment in a BRI country's oil sector positively impacts the volume of oil imports from that country. Specifically, the point estimate of the investment coefficient in the EK-Tobit model is 0.048 and the corresponding marginal effect is 0.12 . This result implies that a $1 \%$ increase in a host country's oil sector investment leads to an approximately $0.12 \%$ increase in imports from that country on average-at the firm level. Our results support the argument that China's energy investment in a BRI country help to promote China's energy security by increasing its imports. Even though there are incidental observations that the equity oil may not be shipped back to China, the overall oil import from the host country increases with the investment. 
Table 3. Estimation results for oil import volume (Equation (2)).

\begin{tabular}{|c|c|c|c|}
\hline Variables & OLS & EK-TOBIT & EK-TOBIT \\
\hline & (1) & (2) & (3) \\
\hline Overseas investment & $\begin{array}{l}0.006^{* *} \\
(0.0022)\end{array}$ & $\begin{array}{c}0.0479 * * * \\
(0.0146)\end{array}$ & \\
\hline Greenfield & & & $\begin{array}{l}0.0411 \text { * } \\
(-0.008)\end{array}$ \\
\hline$M \& A$ & & & $\begin{array}{l}0.0441^{* *} \\
(-0.006)\end{array}$ \\
\hline Market size & $\begin{array}{c}0.746 \\
(0.2512)\end{array}$ & $\begin{array}{c}10.8988 \\
(4.923)\end{array}$ & $\begin{array}{l}10.751 \\
(8.989)\end{array}$ \\
\hline Income & $\begin{array}{c}-0.746 \\
(0.2512)\end{array}$ & $\begin{array}{c}-11.2371 \\
(4.5423)\end{array}$ & $\begin{array}{c}-2.059^{* *} \\
(0.843)\end{array}$ \\
\hline Economic risk & $\begin{array}{l}-0.0027 \\
(0.0027)\end{array}$ & $\begin{array}{l}-0.0445 \\
(0.0515)\end{array}$ & $\begin{array}{l}-0.0035^{* *} \\
(-0.0010)\end{array}$ \\
\hline Oil production & $\begin{array}{c}0.1974^{* * * *} \\
(0.0638)\end{array}$ & $\begin{array}{c}2.4008^{* * *} \\
(0.4054)\end{array}$ & $\begin{array}{l}5.99 * \\
(2.16)\end{array}$ \\
\hline Oil consumption & $\begin{array}{l}-0.1719 \\
(0.1295)\end{array}$ & $\begin{array}{c}-4.168 \\
(3.2367)\end{array}$ & $\begin{array}{c}-0.541 \\
(-0.662)\end{array}$ \\
\hline Constant & $\begin{array}{c}-14.21^{* * *} \\
(-4.6)\end{array}$ & $\begin{array}{c}-143.4 \\
(-98.82)\end{array}$ & $\begin{array}{c}(-17.25) \\
29.02\end{array}$ \\
\hline Year FE & Yes & Yes & Yes \\
\hline Country FE & Yes & Yes & Yes \\
\hline Firm FE & Yes & Yes & Yes \\
\hline $\mathrm{R}^{2}$ & 0.205 & 0.212 & 0.224 \\
\hline Observations & 64,512 & 64,512 & 64,512 \\
\hline
\end{tabular}

Notes: Robust standard errors clustered at the firm level are reported in parentheses. ${ }^{* * *} p<0.01,{ }^{* *} p<0.05,{ }^{*} p<0.1$.

The coefficients of the control variables are consistent with our expectations. Specifically, the coefficients of market size and oil production are significantly positive, and the coefficients of the income variables are negative but not statistically significant. This result suggests that, ceteris paribus, a Chinese firm imports more oil from an BRI country with greater market size and oil production and imports less oil from a higher income country. The significant role of market size and production is also consistent with the findings of previous studies, such as those of [58,59]. The coefficients of economic risk and oil consumption are not statistically significant, indicating they do not affect oil imports. All the time-invariant variables, such as the distance between countries, are dropped out of the model.

Similarly, the estimates of the impact of greenfield investment and M\&A on oil import, reported in Column (3), show that greenfield investments and M\&A both positively affect the volume of oil imports. A t-test shows that the coefficients of these two variables are not statistically different, and, thus, we find no evidence for heterogeneous effects by investment mode.

\section{Conclusions and Policy Implications}

As early as 1993, through its "going out" strategy, the Chinese government encouraged its three major energy companies - the China National Petroleum Corporation, the Sinopec Group and the China National Offshore Oil Corporation-to go abroad and secure supplies of oil and gas through investment, exploration, drilling and the construction of refineries and pipelines. BRI countries have traditionally been the investment destination countries of China. Our empirical results confirmed that China's overseas investment in these countries has enhanced China's energy security both extensively and intensively.

The estimations show that China's overseas investment in energy in a BRI country is positively associated with the probability of importing oil from the country as well as the volume of imports from that country. On average, a $1 \%$ increase in energy OFDI to a country leads to a $1.3 \%$ increase in 
the probability of importing from that country at the firm level. It also leads to an approximately $0.12 \%$ increase in imports from that country at the firm level. In addition, we find that energy security effects do not differ by energy investment mode (M\&A or greenfield).

China's economic development has progressed rapidly since the government initiated reforms to open up the economy, leading to a dramatic increase in China's energy demand in recent years. Our finding clearly indicates that China's going out strategy for securing energy is effective. The countries along the Belt and Road are rich in energy resources and important energy exporters for China. Investment in these countries can help enhance China's energy security by increasing oil import. Stable relations with BRI countries have therefore become increasingly important for Chinese energy security, and the continued development and protection of these relations lies at the core of the "Belt and Road Initiative" strategy. While this study provides an overview of the relationship between energy investment and the oil import between China and BRI countries, the bilateral relationship between China and any BRI county may vary case by case. The study can be considered as complementary to other detailed case studies.

This study mainly focuses on China's oil security and the associated oil investment; however, the potential collaboration opportunities can span the entire energy industrial chain of 65 countries along the Belt and Road countries, with collaborations such as energy infrastructure facilities, oil and gas via oil/gas pipelines, cross-border power transmission facilities and ramping up cooperation in power grid facilities that are upgrading energies. The cooperation should be based on mutual benefits, providing development opportunities for the host countries. Limited by data availability, these issues were not thoroughly examined. Our future research should explore other potentially important collaboration forms and their implications for both China and BRI host countries.

Author Contributions: Conceptualization, B.S.; methodology, B.S.; software, T.C.; validation, B.S. and T.C.; formal analysis, B.S. and T.C.; writing_-original draft preparation, T.C.; writing-review and editing, B.S. All authors have read and agreed to the published version of the manuscript.

Funding: This research was funded by the Humanities and Social Science Fund of Chinese Ministry of Education (No. 19YJA790073) and the Research Project of International Chinese Education Northeast Base at Jilin University (No. 2019DBJDPX01).

Conflicts of Interest: The authors declare no conflict of interest.

\section{References}

1. Zhao, Y.; Liu, X.; Wang, S.; Ge, Y. Energy relations between China and the countries along the Belt and Road: An analysis of the distribution of energy resources and interdependence relationships. Renew. Sustain. Energy Rev. 2019, 107, 133-144. [CrossRef]

2. Duan, F.; Ji, Q.; Liu, B.Y.; Fan, Y. Energy investment risk assessment for nations along China's Belt \& Road Initiative. J. Clean. Prod. 2018, 170, 535-547. [CrossRef]

3. Tan, X. China's overseas investment in the energy/resources sector: Its scale, drivers, challenges and implications. Energy Econ. 2013, 36, 750-758. [CrossRef]

4. Zhang, J.; Sinton, J. Overseas investments by Chinese National Oil Companies. IEA Energy Pap. 2011. [CrossRef]

5. Zhang, Z.X. The overseas acquisitions and equity oil shares of chinese national oil companies: A threat to the west but a boost to china's energy security? Energy Policy 2012, 48, 698-701. [CrossRef]

6. Zhang, Z.X. China's energy security, the Malacca dilemma and responses. Energy Policy 2011, 39, 7612-7615. [CrossRef]

7. Wu, K. China's energy security: Oil and gas. Energy Policy 2014, 73, 4-11. [CrossRef]

8. BP. BP Statistical Review of World Energy; British Petroleum: London, UK, 2019; Available online: http://www.bp.com/content/dam/bp/en/corporate/pdf/energy-economics/statistical-review-2017/bpstatistical-review-of-world-energy-2017-full-report.pdf (accessed on 1 January 2020).

9. IEA. World Energy Statistics. 2019. Available online: https://www.iea.org/classicstats/relateddatabases/ worldenergystatistics/ (accessed on 7 October 2019).

10. IEA. World Energy Outlook 2017; OECD Publishing: Paris, France, 2017. 
11. NDRC. The 13th Five Year Plan of Energy Development. 2016. Available online: http://www.nea.gov.cn/ 2017-01/17/C_135989417.htm (accessed on 7 January 2020).

12. Muller-Kraenner, S. Energy Security; Earthscan: London, UK, 2007.

13. Le, T.-H.; Chang, Y.; Taghizadeh-Hesary, F.; Yoshino, N. Energy Insecurity in Asia: A multi-dimensional analysis. Econ. Model. 2019, 83, 84-95. [CrossRef]

14. Kruyt, B.; van Vuuren, D.P.; de Vries, H.J.; Groenenberg, H. Indicators for energysecurity. Energy Policy 2009, 37, 2166-2181. [CrossRef]

15. Zhang, H.Y.; Ji, Q.; Fan, Y. An evaluation framework for oil import security based on the supply chain with a case study focused on China. Energy Econ. 2013, 38, 87-95. [CrossRef]

16. Sovacool, B.K.; Mukherjee, I. Conceptualizing and measuring energy security: A synthesized approach. Energy 2011, 36, 5343-5355. [CrossRef]

17. Gasser, P. A review on energy security indices to compare country performances. Energy Policy 2020, 139, 111339. [CrossRef]

18. Energy Supply Secur; International Energy Agency: Paris, France, 2014.

19. European Commission. Towards a European Strategy for the Security of Energy Supply; Office for Official Publications of the European Communities: Luxembourg, 2000.

20. Lesbirel, S.H. Diversification and energy security risks: The Japanese case. Jpn. J. Polit. Sci. 2004, 5, 1-22. [CrossRef]

21. Vivoda, V. The Return of the Obsolescing Bargain and the Decline of Big Oil: A Study of Bargaining in the Contemporary Oil Industry; VDM Verlag Dr. Müller: Saarbrücken, Germany, 2008.

22. Vivoda, V. Diversification of oil import sources and energy security: A key strategy or an elusive objective? Energy Policy 2009, 37, 4615-4623. [CrossRef]

23. Alhajji, A.F. What is energy security? Definitions and concepts. Middle East Econ. Surv. 2007, 50, 39-45.

24. Fried, E.R.; Trezise, P.H. Oil Security: Retrospect and Prospect; The Brookings Institution: Washington, DC, USA, 1993.

25. Stringer, K.D. Energy security: Applying a portfolio approach. Balt. Secur. Def. Rev. 2008, 10, 121-142.

26. Cohen, G.; Joutz, F.; Loungani, P. Measuring energy security: Trends in the diversification of oil and natural gas supplies. Energy Policy 2011, 39, 4860-4869. [CrossRef]

27. Vivoda, V.; Manicom, J. Oil Import Diversification in Northeast Asia: A Comparison Between China and Japan. J. East Asian Stud. 2011, 11, 223-254. [CrossRef]

28. Ge, F.; Fan, Y. Quantifying the risk to crude oil imports in China: An improved portfolio approach. Energy Econ. 2013, 40, 72-80. [CrossRef]

29. Du, J.; Zhang, Y. Does One Belt One Road initiative promote Chinese overseas direct investment? China Econ. Rev. 2018, 47. [CrossRef]

30. Han, L.; Han, B.T.; Shi, X.P.; Su, B.; Lv, X.; Lei, X. Energy efficiency convergence across countries in the context of China's Belt and Road initiative. Appl. Energy 2018, 213, 112-122. [CrossRef]

31. Zha, D. "Belt and Road" Initiative: Cooperation Logic and Energy Security. Frontiers 2017, 8, 1-3. (In Chinese)

32. Gao, S.; Jing, Y. Relying on the "One Belt and One Road" strategy to deepen international energy cooperation. Macroecon. Manag. 2016, 3, 17-27. (In Chinese)

33. Wang, Z. The Leading and Demonstration Role of Energy Cooperation in the "Belt and Road" Initiative. Frontiers 2017, 9, 12-19. (In Chinese)

34. Xu, Q.; Cai, L.; Liu, X. Political risk assessment of energy investment in the Belt and Road initiative. Risk Manag. 2017, 25, 201-226. (In Chinese)

35. Sun, Y.; Chen, L.; Sun, H.; Taghizadeh-Hesary, F. Low-carbon financial risk factor correlation in the belt and road PPP project. Financ. Res. Lett. 2020. [CrossRef]

36. Taghizadeh-Hesary, F.; Yoshino, N. The way to induce private participation in green finance and investment. Financ. Res. Lett. 2019, 31, 98-103. [CrossRef]

37. Yoshino, N.; Taghizadeh-Hesary, F.; Nakahigashi, M. Modelling the social funding and spill-over tax for Addressing the green energy financing gap. Econ. Model. 2019, 77, 34-41. [CrossRef]

38. Taghizadeh-Hesary, F.; Yoshino, N. Sustainable Solutions for Green Financing and Investment in Renewable Energy Projects. Energies 2020, 13, 788. [CrossRef]

39. Garrison, J.A. China and the Energy Equation in Asia: The Determinants of Policy Choice; A FirstForumPress Book: London, UK, 2009. 
40. Jiang, J.; Ding, C. Update on Overseas Investments by China's National Oil Companies: Achievements and Challenges since 2011; OECD/IEA: Paris, France, 2014.

41. Bradsher, K. China's Utilities Cut Energy Production, Defying Beijing. New York Times. 24 May 2011. Available online: https://www.nytimes.com/2011/05/25/business/energy-environment/25coal.html (accessed on 17 June 2020).

42. Wolfe, W.M.; Tessman, B.F. China's global equity oil investments: Economic and geopolitical influences. J Strateg. Stud. 2012, 35, 175-196. [CrossRef]

43. Chen, S. Has China's Foreign Energy Quest Enhanced Its Energy Security? China Q. 2011, 600-625.

44. Leung, G.C.K. China's energy security: Perception and reality. Energy Policy 2011, 39, 1330-1337. [CrossRef]

45. Odgaard, O.; Delman, J. China's energy security and its challenges towards 2035. Energy Policy 2014, 71, 107-117. [CrossRef]

46. Gholz, E.; Awan, U.; Ronn, E. Financial and energy security analysis of China's loan-for-oil deals. Energy Res. Soc. Sci. 2017, 24, 42-50. [CrossRef]

47. Chaney, T. Distorted Gravity: The Intensive and Extensive Margins of International Trade. Am. Econ. Rev. 2008, 98, 1707-1721. [CrossRef]

48. Debaere, P.; Shalah, M. Do Tariffs Matter for the Extensive Margin of International Trade? An Empirical Analysis. J. Int. Econ. 2010, 88, 163-169. [CrossRef]

49. Mityakov, S.; Tang, H.; Tsui, K.K. International politics and import diversification. J. Law Econ. 2013, 56, 1091-1121. [CrossRef]

50. Kashcheeva, M.; Tsui, K.K. Political oil import diversification by financial and commercial traders. Energy Policy 2015, 82, 289-297. [CrossRef]

51. American Enterprise Institute \& Heritage Foundation. China Global Investment Tracker. 2018. Available online: http://www.aei.org/china-global-investment-tracker/ (accessed on 20 December 2019).

52. Luo, L.; Zhen, Q.; Hubbard, P. Not looking for trouble: Understanding large-scale chinese oversea investment by sector and owership. China Econ. Rev. 2017, 46, 142-164. [CrossRef]

53. Eaton, J.; Kortum, S. Trade in capital goods. European Econ. Rev. 2001, 45, 1195-1235. [CrossRef]

54. Head, K.; Mayer, T. Gravity equations: Workhorse, toolkit, and cookbook. Handb. Int. Econ. 2014, 4, 131-195. [CrossRef]

55. Cheptea, A.; Emlinger, C.; Latouche, K. Do exporting firms benefit from retail internationalization? Evidence from France. CEPII Working Paper 2015, 21. Available online: http://www.cepii.fr/CEPII/en/publications/wp/ abstract.asp?NoDoc=8423 (accessed on 10 January 2020).

56. Gaigné, C.; Latouche, K.; Turolla, S. Vertical ownership and export performance: Firm-level evidence from the food industry. Am. J. Agric. Econ. 2018, 100, 46-72. [CrossRef]

57. Harms, P.; Méon, P.G. Good and useless FDI: The growth effects of greenfield investment and mergers and acquisitions. Rev. Int. Econ. 2018, 26, 37-59. [CrossRef]

58. Buckley, P.J.; Clegg, L.J.; Cross, A.R.; Liu, X.; Voss, H.; Zheng, P. The determinants of Chinese outward foreign direct investment. J. Int. Bus. Stud. 2007, 38, 499-518. [CrossRef]

59. Urdinez, F.; Masiero, G.; Ogasavara, M. China's quest for energy through FDI: New empirical evidence. J. Chin. Econ. Bus. Stud. 2014, 12, 293-314. [CrossRef]

(C) 2020 by the authors. Licensee MDPI, Basel, Switzerland. This article is an open access article distributed under the terms and conditions of the Creative Commons Attribution (CC BY) license (http://creativecommons.org/licenses/by/4.0/). 